\title{
TEMATIK HADIS TENTANG RIBA DALAM KITAB SHAHIH BUKHARI
}

\author{
Nurhadi* \\ *Sekolah Tinggi Agama Islam (STAI) Al-Azhar Pekanbaru \\ Jl. KH. Ahmad Dahlan No.96, Kp. Melayu, Kec. Sukajadi, Kota Pekanbaru, Riau 28122 \\ Email: alhadijurnal@gmail.com
}

\begin{abstract}
Abstrak: Islam adalah agama yang komprehensif yang merangkum seluruh kehidupan manusia termasuk kegiatan ekonomi. Era zaman modern dan serba canggih ini, fenomena perkembangan kegiatan bisnis yang ada harus di waspadai, agar tidak terjerumus prekatek riba. Lalu bagaimana menurut hadis dalam shahih bukhari berkaitan dengan riba? Hasil penelitian dapat disimpulkan bahwa dalam kitab mausu'ah al-hadis al-Nabawiyah, dari persepktif shahih bukhari berkaitan dengan riba, penulis temukan ada 86 hadis dari riwayat bukhari. Dari 86 tersebut diambil sampel 5 hadis, yaitu hadis nomor 439 dalam kitab shahih bukhari, maka akan muncul pada Kitab: Shalat, Bab: Haramnnya memperdagangkan khamar di dalam masjid (sebelum turun ayat pengharaman meminumnya), No. Hadist: 439. Hadis Bukhari No. 439. Selanjutnya hadis nomor 1943 dalam kitab shahih bukhari, maka akan muncul pada Kitab: Jual beli, Bab: Pemakan riba, saksi dan penulisnya, No. Hadist: 1943. Kemudian hadis nomor 1944 dalam kitab shahih bukhari, maka akan muncul pada Kitab: Jual beli, Bab: Orang yang memberi makan riba, No. Hadist: 1944. berikutnya hadis nomor 2032 dalam kitab shahih bukhari, maka akan muncul pada Kitab: Jual beli, Bab: Menjual dinar dengan dinar secara tempo, No. Hadist: 2032.
\end{abstract}

Kata Kunci : Tematik, Hadis, Riba, Shahih, Bukhari. 


\section{PENDAHULUAN}

Islam adalah agama yang komprehensif yang merangkum seluruh kehidupan manusia termasuk kegiatan ekonomi. Pelaksanaan Islam secara menyeluruh akan membawa rahmat kepada sekalian alam termasuk manusia yang menjalankan kegiatan ekonomi (Boy Syamsul, 2011: 48-49). Era zaman modern dan serba canggih ini perkembangan sistem ekonomi sudah sangat pesat. Beragam sistem ditawarkan oleh para pembisnis untuk bersaing menggaet hati para pelanggan. Seorang ekonomi muslim yang tidak hanya berorientasi pada keuntungan dunia saja, sudah semestinya harus cerdik, juga senantiasa menganalisa fenomena perkembangan kegiatan bisnis yang ada, supaya mengetahui pandangan syariat terhadap suatu transaksi bisnis, sehingga tidak mudah terjerumus ke dalam larangan-Nya (riba) (Muslim, 2018).

Kegiatan ekonomi bisnis yang sangat di gemari kebanyakan masyarakat adalah jual beli kredit. Salah satu transaksi yang cepat mendapatkan barang dan keuntungan adalah jual beli kredit. Diantara jual akad jual beli yang dilarang dengan pelanggaran yang keras antara lain adalah Riba. Dalam Islam, memungut riba atau mendapatkan keuntungan berupa riba pinjaman adalah haram. Ini dipertegas dalam al-Qur'an Surah alBaqarah ayat 275 yang artinya: "Orangorang yang makan (mengambil) riba (Riba itu ada dua macam: nasiah dan fadhl. riba nasiah ialah pembayaran lebih yang disyaratkan oleh orang yang meminjamkan. riba fadhl ialah penukaran suatu barang dengan barang yang sejenis, tetapi lebih banyak jumlahnya Karena orang yang menukarkan mensyaratkan demikian, seperti penukaran emas dengan emas, padi dengan padi, dan sebagainya. riba yang dimaksud dalam ayat Ini riba nasiah yang berlipat ganda yang umum terjadi dalam masyarakat Arab zaman Jahiliyah) tidak dapat berdiri melainkan seperti berdirinya orang yang kemasukan syaitan lantaran (tekanan) penyakit gila (maksudnya: orang yang mengambil riba tidak tenteram jiwanya seperti orang kemasukan syaitan.). keadaan mereka yang demikian itu, adalah disebabkan mereka Berkata (berpendapat), Sesungguhnya jual beli itu sama dengan riba, padahal Allah Telah menghalalkan jual beli dan mengharamkan riba. orang-orang yang Telah sampai kepadanya larangan dari Tuhannya, lalu terus berhenti (dari mengambil riba), Maka baginya apa yang Telah diambilnya dahulu (riba yang sudah diambil (dipungut) sebelum turun ayat ini, boleh tidak dikembalikan) (sebelum datang larangan); dan urusannya (terserah) kepada Allah. orang yang kembali (mengambil riba), Maka orang itu adalah penghuni-penghuni neraka; mereka kekal di dalamnya" (Depag RI, 2015: 69).

Selain firman allah swt diatas, juga menjadi dalil tentang riba, terdapat dalam surah al-Imran ayat 130 sebagai berikut, yang artinya: "Hai orang-orang yang beriman, janganlah kamu memakan riba dengan berlipat ganda (yang dimaksud riba di sini ialah riba nasi'ah. menurut sebagian besar ulama bahwa riba nasi'ah itu selamanya Haram, walaupun tidak berlipat ganda. Riba itu ada dua macam: nasiah dan fadhl. riba nasiah ialah pembayaran lebih yang disyaratkan oleh orang yang meminjamkan. riba fadhl ialah penukaran suatu barang dengan barang yang sejenis, tetapi lebih banyak jumlahnya Karena orang yang menukarkan mensyaratkan demikian, seperti penukaran emas dengan emas, padi dengan padi, dan sebagainya. riba yang dimaksud dalam ayat Ini riba nasiah yang berlipat ganda yang umum terjadi dalam masyarakat Arab zaman Jahiliyah) dan bertakwalah kamu kepada Allah 
supaya kamu mendapat keberuntungan" (Depag RI, 2015: 97).

Dalam surah al-Baqarah ayat 276 sebagai berikut, yang artinya: "Allah memusnahkan riba dan menyuburkan sedekah (yang dimaksud dengan memusnahkan riba ialah memusnahkan harta itu atau meniadakan berkahnya. dan yang dimaksud dengan menyuburkan sedekah ialah memperkembangkan harta yang Telah dikeluarkan sedekahnya atau melipat gandakan berkahnya). dan Allah tidak menyukai setiap orang yang tetap dalam kekafiran, dan selalu berbuat dosa (maksudnya ialah orang-orang yang menghalalkan riba dan tetap melakukannya)" (Depag RI, 2015: 69).

Dalam surah al-Baqarah ayat 278279 sebagai berikut, yang artinya: "Hai orang-orang yang beriman, bertakwalah kepada Allah dan tinggalkan sisa riba (yang belum dipungut) jika kamu orangorang yang beriman. Maka jika kamu tidak mengerjakan (meninggalkan sisa riba), Maka Ketahuilah, bahwa Allah dan rasulNya akan memerangimu. dan jika kamu bertaubat (dari pengambilan riba), Maka bagimu pokok hartamu; kamu tidak menganiaya dan tidak (pula) dianiaya" (Depag, 2015: 69-70).

Dan di antara hadis yang terkait dengan riba yang artinya: "Telah menceritakan kepada kami Utsman bin Abu Syaibah dan Ishaq bin Ibrahim dan ini adalah lafadz Utsman. Ishaq berkata; telah mengabarkan kepada kami, dan Utsman berkata; telah menceritakan kepada kami Jarir dari Mughirah dia berkata, "Syibak bertanya kepada Ibrahim, lalu ia menceritakan kepada kami dari 'Alqamah dari Abdullah dia berkata, "Rasulullah shallallahu 'alaihi wasallam melaknat orang yang memakan hasil riba dan yang menyuruh memakannya." 'Alqamah berkata, "Saya bertanya, "(Bagaimana dengan) sekretaris pembuat akte riba dan saksi-saksinya?" dia menjawab, "Kami hanya menceritakan dari sesuatu yang kami dengar." (HR. Muslim No. 2994).

Melalui ayat dan hadis diatas, agar secara detail hadis-hadis tentang riba dalam shahih bukhari yang menjadi rujukan utama setelah al-qur'an. Maka dalam tulisan penelitian ini akan membahas teks nash hadis Nabi saw dalam masalah riba dalam kitab hadis shahih bukhar.

\section{TINJAUAN PUSTAKA}

\section{Biografi Imam Bukhari}

Namanya Abu Abdillah

Muhammad bin Isma'il bin Ibrahim bin alMughirah bin Bardizbah al-Ju'fi alBukhari. Lahir di Bukhara, hari jim'at 13 syawal $194 \mathrm{H}$, wafat di Samarqand (M. Agus, 2013: 230) tanggal 30 Ramadhan malam sabtu hari raya waktu isya' $256 \mathrm{H}$ (A. Qadir Hassan, 2012: 436), pada usia 62 tahun (M. Abdurrahman, 2003: 45). Beliau dikenal sebagai al-Bukhari, Tidak lama setelah beliau lahir, beliau kehilangan penglihatannya. Seorang Muhadditsin yang jarang tandingannya ini, sangat wara', sedikit makan, banyak membaca Al- Qur'an, baik siang maupaun malam, serta gemar berbuat kebajikan kepada murid- muridnya (Fatchur Rahman, 1974: 375-376).

Imam Bukhari di didik dalam keluarga yang taat beragama, ayahnya adalah seorang ulama bermazhab Maliki dan merupakan murid dari imam Malik, seorang ulama besar dan ahli fiqih, ayahnya wafat ketika beliau masih kecil (Endang Soetari, 2008: 280;M Alawi, 2012: 256; M. Agus, 2013: 230), beliau mulai menuntut ilmu sejak usia dini tahun $205 \mathrm{H}$, beliau berguru kepada as-syaikh ad-dakhili ulama ahli hadis yang masyhur di Bukhara, pada usia 16 tahun dia bersama keluarganya mungunjugi kota Makkah dan Madinah, dikedua kota tersebut dia mengikuti kuliah para guru besar hadis (Agus Sdan Agus S, 2008: 231). Bukhari pergi menjumpai guru-guru 
hadis diberbagai negeri, dia pergi ke Bagdad, Basrah, Kuffah, Makkah, Madinah, Syam, Mesir (Abdul Majid Khon, 2010: 259). Dia belajar dari banyak guru dan menulis dari seribu guru, kecintaan beliau terhadap ilmu yang mengantarkan beliau ke puncak keilmuan saat itu, bahkan sampai menjadi imam kaum muslimin dalam bidang hadis. Tokoh-tokoh memberikan julukan kepada beliau amirul mu'minin fi al-hadis, beliau sangat terkenal wara' ahli ibadah selain ahli ilmu (Muhammad A'jal, 1998: 76).

Beliau dalam penelitian hadis untuk mengumpulkan dan menyeleksi hadis shahih menghabiskan waktu 16 tahun untuk mengunjungi diberbagai kota untuk menemui para perawi hadis, mengumpulkan dan menyeleksi hadisnya (Nawir Yuslem, 2006: 51). Ketika di bagdad tidak semua hadis yang beliau hafal kemudian diriwayatkan, tetapi diseleksi terlebih dahulu dengan penyeleksian yang ketat, apakah sanad dari hadis tersebut bersambung dan apakah perawi hadis itu terpercaya dan tsiqah (kuat), akhirnya bukhari menulis sebanyak 9082 hadis dalam kitabnya alJami' al-Shahih, karyanya antara lain: shahih bukhari, al-Adab al-Mufrad, alDu'afa' al-Shaghir, at-Tarikh al-Shaghir, al-Ttarikh al-Ausath (Nawir Yuslem, 2006: 51).

Beliau seorang imam yang tidak tercela hapalan hadisnya dan kecermatannya, beliau mulai menghapal hadis ketika umurnya belum mencapai 10 tahun, dia mencatat dari 1000 guru lebih, hapal 100.000 hadis shahih dan 200.000 hadis yang tidak shahih (Nawir Yuslem, 2006: 51). Dialah pengarang kitab besar Al-jami' al-Shahih yang merupakan kitab paling sahih sesudah al-Qur'an (Subhi alShalih, 2007: 280).

\section{Konsep Riba dalam Islam}

Pada dasarnya transaksi riba dapat terjadi dari transaksi hutang piutang, namun bentuk dari sumber tersebut bisa berupa qard, Qard berasal dari kata يقرض قرض - yang berarti pinjaman (Ahmad Munawir, 1997: 1108), menurut Abdurrahman al-Jaziri (1972: 338) qard adalah harta yang diambil oleh orang yang meminjam karena orang yang meminjam tersebut memotong dari harta miliknya, buyu', Menurut Abdullah alMushlih dan Shalah ash-Shawi jual beli adalah dua kata yang saling berlawanan artinya, namun masing-masing sering digunakan untuk arti kata yang lain secara bergantian. Oleh sebab itu, masingmasing dalam akad transaksi disebut sebagai pembeli dan penjual. Rasulullah saw. Bersabda, "dua orang yang berjual beli memiliki hak untuk menentukan pilihan, sebelum mereka berpindah dari lokasi jual beli." Akan tetapi bila disebutkan secara umum, yang terbetik dalam hak adalah bahwa kata penjual diperuntukan kepada orang yang mengeluarkan barang dagangan. Sementara pembeli adalah orang yang mengeluarkan bayaran. Penjual adalah yang mengeluarkan barang miliknya. Sementara pembeli adalah orang yang menjadikan barang itu miliknya dengan kondisi kompensasi pembayaran (Abdullah al-Mushlih, 2004: 89-90) menurut Chairuman Pasaribu dan Suhrawardi K. Lubis (2004: 33): Kata Jual beli terdiri dari dua suku kata yaitu jual dan beli. Sebenarnya kata "jual" dan "beli" mempunyai arti satu sama lainnya bertolak belakang dan lain sebagainya. Para ulama menetapkan dengan tegas dan jelas tentang pelarangan riba, disebabkan riba mengandung unsur eksploitasi yang dampaknya merugikan orang lain, hal ini mengacu pada Kitabullah dan Sunnah Rasul serta ijma' para ulama. Bahkan dapat dikatakan tentang pelarangannya sudah menjadi aksioma dalam ajaran Islam (Abdullah al-Mushlih, 2004: 345). Kata riba berasal dari bahasa Arab, secara 
etimologis berarti tambahan (azziyadah) (Abu Sura'I, 2003: 125), berkembang (annumuw), membesar (al-'uluw), menurut Syaikh Abul A'la al-Maududi An-Numuw (2004: 110) adalah pertumbuhan dan $A l$ 'Uluw adalah tinggi. dan meningkat (alirtifa'). Sehubungan dengan arti riba dari segi bahasa tersebut, ada ungkapan orang Arab kuno menyatakan sebagai berikut; arba fulan 'ala fulan idza azada 'alaihi (seorang melakukan riba terhadap orang lain jika di dalamnya terdapat unsur tambahan atau disebut liyarbu ma a'thaythum min syai'in lita'khuzu aktsara minhu (mengambil dari sesuatu yang kamu berikan dengan cara berlebih dari apa yang diberikan) (Khoiruddin, 2006: 37).

\section{METODE}

Jenis penelitian ini adalah termasuk penelitian kualitatif, karena sifat data yang akan dikumpulkan bercorak kualitatif (Lexy J Moleong, 2001: 11; Imam Suprayogo, 2002: 9; Bungin Burhan, 2004: 31). Oleh karena itu data penelitian bersifat naturalis dengan memakai logika induktif dan pelaporannya bersifat deskriptif (Hadari Nawawi, 2009: 67; Dedy Mulyana, 2005: 27). Penelitian ini terfokus pada penelitian kepustakaan (library research) atau studi teks (Iskandar, 2010: 29; HB Sutopo, 2004: 17). Maka penelitian ini akan lebih memusatkan perhatian pada pengkajian-pengkajian terhadap teks, dan termasuk jenis penelitian kualitatif (Hamidi, 2004: 13; Neong Muhajir, 1998: 17). Penelitian kepustakaan dilakukan karena sumber-sumber datanya, baik yang utama (primary resources) maupun pendukung (secondary resources) seluruhnya adalah teks (Muhammad Nazir, 1997: 58; Sugiyono, 2006: 21). Dalam hal ini sumbernya adalah kitab mausu'ah al-Hadis al-Nabawiyah dan tematiknya (al-Mausu'ah digital sofwer).

\section{PEMBAHASAN}

Penelitian penulis dalam kitab mausu'ah al-hadis al-Nabawiyah, dari persepktif hadis shahih bukhari. Maka dapat ditemukan hadis berkaitan dengan riba sebanyak 86 hadis dalam kitab tersebut, dimulai dari hadis nomor 439 s/d 6894. Lihat tabel mausu'ahnya sebagai berikut: 
Tabel 1: Hadis Berkaitan Dengan Riba

\begin{tabular}{|c|c|c|c|}
\hline No & Hadis No & Judul dalam Kitab Hadis & Teks Naskah Arab Kitab Hadis \\
\hline 1 & 439 & $\begin{array}{l}\text { Haramnnya memperdagangkan } \\
\text { khamer di dalam masjid (sebelum } \\
\text { turun ayat pengharaman } \\
\text { meminumnya) }\end{array}$ & 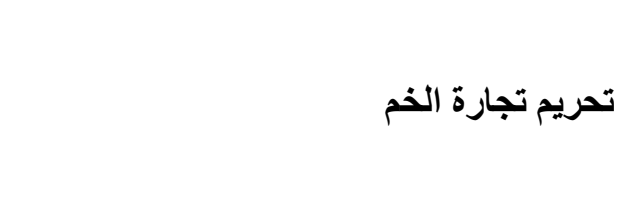 \\
\hline 2 & 812 & $\begin{array}{l}\text { Tentang Wudlu'nya Anak-anak dan } \\
\text { Kapan Mereka Diwajibkan Mandi, } \\
\text { Bersuci Dan Kehadiran Mereka Pada } \\
\text { Shalat Jama'ah di Masjid }\end{array}$ & و والطهور وحضيور ومتى يجب عليهم الغسل \\
\hline 3 & 937 & Tentang Shalat Witir & ما جاء في الوتر \\
\hline 4 & 1204 & $\begin{array}{l}\text { Sabda Nabi saw tentang Mayat Akan } \\
\text { Disiksa Disebabkan Tangisan } \\
\text { Keluarganya }\end{array}$ & بيعضل النبي صلى الله عليه وسلم يعذب الميت \\
\hline 5 & 1297 & $\begin{array}{l}\text { Pembicaraan Tentang Keberadaan } \\
\text { Mayit dari Anak-anak Kaum } \\
\text { Musyrikin }\end{array}$ & ما قيل في أولاد المشركين \\
\hline 6 & 1534 & $\begin{array}{l}\text { Wajibnya sai antara Shafa dan Marwa, } \\
\text { dan Allah menjadikannya termasuk } \\
\text { dari syiar-syiar Nya }\end{array}$ & وجوب الصفا والمروة وجعل من شعائر الله \\
\hline 7 & 1538 & Sai antara Shafa dan Marwa & ما جاء في السعي بين الصفا والمروة \\
\hline 8 & 1665 & $\begin{array}{l}\text { Melakukan dalam umrah } \\
\text { sebagaimana yang dilakukan dalam } \\
\text { haji }\end{array}$ & يفعل في العمرة ما يفعل في الحج \\
\hline 9 & 1943 & Pemakan riba, saksi dan penulisnya, & آكل الربا وشاهده وكاتبه \\
\hline 10 & 1944 & Orang yang memberi makan riba & 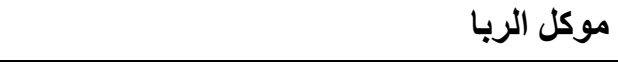 \\
\hline 11 & 1990 & $\begin{array}{l}\text { Penjelasan tentang jual beli dan } \\
\text { penimbunan }\end{array}$ & ما يذكر في بيع الطعام والحكرة \\
\hline 12 & 1997 & Jual beli muzabanah & بيع المزايدة \\
\hline 13 & 2025 & $\begin{array}{l}\text { Menjual buah kurma dengan buah } \\
\text { kurma }\end{array}$ & بيع التمر بالتمر \\
\hline 14 & 2028 & Menjual gandum dengan gandum & بيع الثعير بالثعير \\
\hline 15 & 2032 & $\begin{array}{l}\text { Menjual dinar dengan dinar secara } \\
\text { tempo }\end{array}$ & 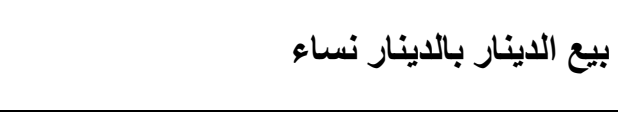 \\
\hline
\end{tabular}

SYARIKAT : Jurnal Rumpun Ekonomi Syariah Volume 2, Nomor 1, Juni 2019 
p-ISSN 2654-3923

e-ISSN 2621-6051

\begin{tabular}{|c|c|c|c|}
\hline 16 & 2068 & $\begin{array}{l}\text { Membeli, menghibahkan dan } \\
\text { memerdekakan buda dari orang kafir } \\
\text { harbi }\end{array}$ & شراء المملوك من الحربي و هبته وعتقه \\
\hline 17 & 2084 & Harga anjing & تمن الكلب \\
\hline 18 & 2134 & $\begin{array}{l}\text { Bertentangganya Abu Bakar di masa } \\
\text { Rasulullah saw }\end{array}$ & وسلم وعقده أبكر في عهد النبي صلى الله عليه \\
\hline 19 & 2145 & $\begin{array}{l}\text { Jika wakil menjual sesuatu yang } \\
\text { rusak, maka jual belinya ditolak }\end{array}$ & إذا باع الوكيل شيئا فاسدا فبيعه مردود \\
\hline 20 & 2228 & $\begin{array}{l}\text { Orang yang menjual harta orang yang } \\
\text { sedang bangkrut, atau orang yang } \\
\text { tidak punya }\end{array}$ & الغرماء أو مال المفلس أو المعدم فقسمه بين \\
\hline 21 & 2360 & $\begin{array}{l}\text { Seorang buda jika ia beribadah } \\
\text { dengan baik dan patuh kepada } \\
\text { tuannya }\end{array}$ & العبد إذا أحسن عبادة ربه ونصح سيده \\
\hline 22 & 2363 & $\begin{array}{l}\text { Seorang buda jika ia beribadah } \\
\text { dengan baik dan patuh kepada } \\
\text { tuannya }\end{array}$ & العبد إذا أحسن عبادة ربه ونصح سيده \\
\hline 23 & 2364 & $\begin{array}{l}\text { Larangan memperpanjang } \\
\text { perbudakan }\end{array}$ & كتي أمية التطاول على الرقيق وقوله عبدي أو \\
\hline 24 & 2365 & $\begin{array}{l}\text { Larangan memperpanjang } \\
\text { perbudakan }\end{array}$ & كراهية التطاول على الرقيق وقوله عبدي أو \\
\hline 25 & 2479 & $\begin{array}{l}\text { Firman Allah "Sesungguhnya orang- } \\
\text { orang yang menukar janji (nya } \\
\text { dengan) Allah..." }\end{array}$ & وأيمانهم الله تعالى إن الذين يشترون بعهل الله \\
\hline 26 & 2560 & $\begin{array}{l}\text { Firman Allah "Sesungguhnya orang- } \\
\text { orang yang makan harta anak yatim } \\
\text { secara zhalim..." }\end{array}$ & ظقلمال الله تعالى إن الذين يأكلون أموال اليتامى \\
\hline 27 & 2644 & Nama kuda dan keledai & اسم الفرس والحمار \\
\hline 28 & 2678 & Keutamaan ribath di jalan Allah & فضل رباط يوم في سبيل الله \\
\hline 29 & 3112 & $\begin{array}{l}\text { Firman Allah "Dan Allah telah } \\
\text { mengangkat nabi Ibrahim sebagai } \\
\text { kekasih-Nya" }\end{array}$ & قول الله تعالى واتخذ الله إبراهيم خليلا \\
\hline 30 & 3113 & $\begin{array}{l}\text { Firman Allah "Dan Allah telah } \\
\text { mengangkat nabi Ibrahim sebagai } \\
\text { kekasih-Nya" }\end{array}$ & قول الله تعالى واتخذ الله إبراهيم خليلا \\
\hline 31 & 3114 & Firman Allah "Dan Allah telah & قول الله تعالى واتخذ الله إبراهيم خليلا \\
\hline
\end{tabular}

SYARIKAT : Jurnal Rumpun Ekonomi Syariah Volume 2, Nomor 1, Juni 2019 


\begin{tabular}{|c|c|c|c|}
\hline & & $\begin{array}{l}\text { mengangkat nabi Ibrahim sebagai } \\
\text { kekasih-Nya" }\end{array}$ & \\
\hline 32 & 3235 & $\begin{array}{l}\text { Firman Allah "Hai manusia, } \\
\text { sesungguhnya kami menciptakan laki- } \\
\text { laki dan perempuan dan kami jadikan } \\
\text { kalian ..." }\end{array}$ & ذكر وأنثى تعالى يا أيها الناس إنا خلقتاكم من \\
\hline 33 & 3296 & Sifat Nabi saw & صفة النبي صلى الله عليه وسلم \\
\hline 34 & 3317 & Tanda kenabian dalam Islam & علامات النبوة في الإسلام \\
\hline 35 & 3530 & Sifat terpuji Abdullah bin Salam & مناقب عبد الله بن سلام رضي الله عنه \\
\hline 36 & 3611 & Hijrahnya Nabi saw ke Madinah & الدجينة النبي صلى الله عليه وسلم وأصحابه إلى \\
\hline 37 & 3616 & Hijrahnya Nabi saw ke Madinah & الديزةة النبي صلى الله عليه وسلم وأصحابه إلى \\
\hline 38 & 3826 & Hadits Ifki & 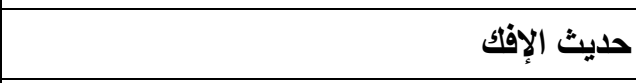 \\
\hline 39 & 3863 & Pertempuran Hudaibiyah & غزوة الحديبية \\
\hline 40 & 3957 & $\begin{array}{l}\text { Posisi Nabi saw saat penaklukan } \\
\text { Makkah }\end{array}$ & منزل النبي صلى الله عليه وسلم يوم الفتح \\
\hline 41 & 3970 & $\begin{array}{l}\text { Laits berkata "Yunus telah } \\
\text { menceritakan kepadaku dari Ibnu } \\
\text { Syihab, }\end{array}$ & أخبرني عبد اللهني يونس عن ابن شهاب \\
\hline 42 & 4135 & [Bab] Surat al Baqarah ayat 158 & قالبيته إن الصفا و المروة من شعائر الله فمن حج \\
\hline 43 & 4136 & [Bab] Surat al Baqarah ayat 158 & قالبيته إن الصفا والمروة من شعائر الله فمن حج \\
\hline 44 & 4176 & [Bab] Surat al Baqarah ayat 275 & وأحل الله البيع وحرم الربا \\
\hline 45 & 4180 & [Bab] Surat al Baqarah ayat 280 & واتقوا يوما ترجعون فيه إلى الله \\
\hline 46 & 4204 & [Bab] Surat Ali Imran ayat 191 & و الذينكرون \\
\hline 47 & 4205 & [Bab] Surat Ali Imran ayat 192 & رينا إنك من تدخل النار فقد أخزيته وما \\
\hline 48 & 4206 & [Bab] Surat Ali Imran ayat 193 & ربنا إنتا سمغنا مناديا ينادي للإيمان الآية \\
\hline 49 & 4215 & [Bab] Surat An Nisaa` ayat 40 & قوله إن الله لا يظلم مثقال ذرة يعني زنة ذرة \\
\hline 50 & 4404 & [Bab] Surat Luqma ayat 34 & قوله إن الله عذده علم الساعة \\
\hline 51 & 4572 & Qutaibah telah menceritakan kepada & حدثا قتيبة حدثنا حماد عن يحيى بن عتيق عن \\
\hline
\end{tabular}

SYARIKAT : Jurnal Rumpun Ekonomi Syariah Volume 2, Nomor 1, Juni 2019 


\begin{tabular}{|c|c|c|c|}
\hline & & kami, & 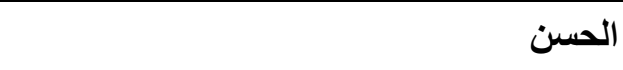 \\
\hline 52 & 4878 & $\begin{array}{l}\text { Nikahnya wanita musyrik yang masuk } \\
\text { Islam, lalu bagaimana dengan iddah } \\
\text { mereka? }\end{array}$ & نكاح من أسلم من المشركات وعدتهن \\
\hline 53 & 4928 & $\begin{array}{l}\text { Mahar untuk wanita pelacur dan } \\
\text { nikah yang rusak }\end{array}$ & مهر البغي والنكاح الفاسد \\
\hline 54 & 4969 & Makan roti berkuah & الخبز المرقق والأكل على الخوان و السفرة \\
\hline 55 & 5084 & Sembelihan ahli kitab & وغيائح أهل الكتاب وشحومها من أهل الحرب \\
\hline 56 & 5160 & $\begin{array}{l}\text { Penjelasan bahwa khamer adalah } \\
\text { sesuatu yang merubah akal }\end{array}$ & ما جاء في أن الخمر ما خامر العقل من الثراب \\
\hline 57 & 5182 & Mencampur air dengan susu & شوب اللبن بالماء \\
\hline 58 & 5190 & Minum langsung dari dalam kolam & الكرع في الحوض \\
\hline 59 & 5194 & Memecah mulut bejana & اختناث الأسقية \\
\hline 60 & 5195 & Memecah mulut bejana & اختناث الأسقية \\
\hline 61 & 5196 & Minum dari mulut bejana (ceret) & الثرب من فم السقاء \\
\hline 62 & 5197 & Minum dari mulut bejana (ceret) & الثرب من فم السقاء \\
\hline 63 & 5198 & Minum dari mulut bejana (ceret) & الثرب من فم السقاء \\
\hline 64 & 5275 & $\begin{array}{l}\text { Obat yang dimasukkan lewat mulut } \\
\text { (Alladud) }\end{array}$ & اللاود \\
\hline 65 & 5489 & Tato & 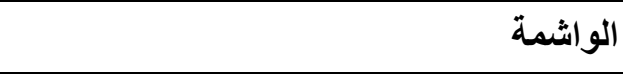 \\
\hline 66 & 5505 & Yang melaknat penggambar & من لعن المصور \\
\hline 67 & 5510 & Laki-laki membonceng laki-laki & إرداف الرجل خلف \\
\hline 68 & 5511 & Wanita membonceng laki-laki & إرداف المرأة خلف الرجل \\
\hline 69 & 5524 & Keutamaan shilatu rahim & فضل صلة الرحم \\
\hline 70 & 5796 & $\begin{array}{l}\text { Menjawab dengan "Labbaika wa } \\
\text { sa'daika" }\end{array}$ & من أجاب بلبيك وسعديك \\
\hline 71 & 5906 & Doa jika ingin bepergian atau pulang & الدعاء إذا أراد سفرا أو رجع \\
\hline 72 & 5929 & $\begin{array}{l}\text { Keutamaan mengingat Allah Azza wa } \\
\text { jalla }\end{array}$ & فضل ذكر الله عز وجل \\
\hline 73 & 6013 & $\begin{array}{l}\text { Mengisolir diri, istirahat dari kawan- } \\
\text { kawan jahat }\end{array}$ & العزلة راحة من خلاط السوء \\
\hline
\end{tabular}

SYARIKAT : Jurnal Rumpun Ekonomi Syariah Volume 2, Nomor 1, Juni 2019 
p-ISSN 2654-3923

e-ISSN 2621-6051

\begin{tabular}{|c|c|c|c|}
\hline 74 & 6019 & $\begin{array}{l}\text { Menyungguhi diri untuk taat kepada } \\
\text { Allah }\end{array}$ & ، جاهد نفسه في طاعة الله \\
\hline 75 & 6080 & Sifat surga dan neraka & فة الجنة والنار \\
\hline 76 & 6192 & $\begin{array}{l}\text { Bersumpah tidak akan minum } \\
\text { perasan, lantas minum juice atau gula }\end{array}$ & إن حلف أن لا يشرب نبيذا فشرب طلاء أو \\
\hline 77 & 6194 & $\begin{array}{l}\text { Bersumpah untuk tidak berlauk, } \\
\text { lantas makan kurma dengan roti dan } \\
\text { segala hal yang berlauk }\end{array}$ & إذا حلف أن لا يأتدم فأكل تمرا بخبز وما يكون \\
\hline 78 & 6288 & $\begin{array}{l}\text { Menegakkan hukuman untuk menjaga } \\
\text { kehormatan Allah }\end{array}$ & إقامة الحدود والانتقام لحرمات الله \\
\hline 79 & 6308 & Keutamaan meninggalkan dosa & فضل من ترك الفواحش \\
\hline 80 & 6347 & Hukuman pendidikan & 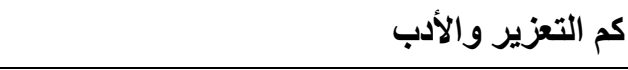 \\
\hline 81 & 6351 & $\begin{array}{l}\text { Menuduh wanita baik-baik } \\
\text { melakukan perzinahan }\end{array}$ & كنات \\
\hline 82 & 6467 & Wahyu pertama-tama & من الوح ما بدئ به رسول الله صلى الله عليه وسلم \\
\hline 83 & 6525 & $\begin{array}{l}\text { Menakwilkan mimpi setelah shalat } \\
\text { subuh }\end{array}$ & ير الروئيا بعد صلاة الصبح \\
\hline 84 & 6705 & $\begin{array}{l}\text { Dibolehkan berita satu orang sebagai } \\
\text { hujjah (argumentasi) }\end{array}$ & ل ازة خبر الواحد \\
\hline 85 & 6825 & $\begin{array}{l}\text { Ajakan Nabi saw kepada umatnya } \\
\text { untuk mentauhidkan Allah Ta'ala }\end{array}$ & جاء إلى في دعاء النبي صلى الله عليه وسلم \\
\hline 86 & 6894 & $\begin{array}{l}\text { Firman Allah Ta'ala: }\{\text { Sesungguhnya } \\
\text { rahmat Allah amat dekat kepada } \\
\text { orang-orang yang berbuat baik\} }\end{array}$ & ون الله تعالى إن رحمة الله قريب \\
\hline
\end{tabular}

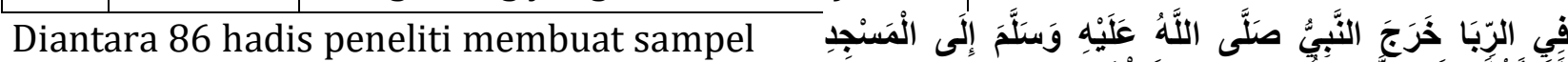
5 hadis, yaitu hadis 439, 1943, 1944, 2032 dan 4180. Jika dilihat dari hadis 439 dalam kitab shahih bukhari, maka akan muncul pada Kitab: Shalat, Bab: Haramnnya memperdagangkan khamer di dalam masjid (sebelum turun ayat pengharaman meminumnya), No. Hadist : 439, hadisnya sebagai berikut:

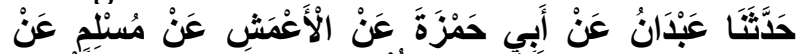

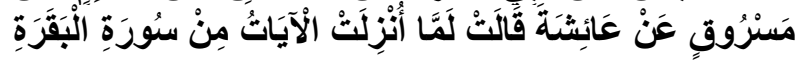

Artinya: Telah menceritakan kepada kami 'Abdan dari Abu Hamzah dari AlA'masy dari Muslim dari Masruq dari 'Aisyah berkata, "Ketika turun ayat-ayat dalam Surah Al-Baqarah tentang masalah riba, Nabi saw keluar ke masjid lalu membacakan ayat-ayat tersebut kepada manusia. Kemudian beliau mengharamkan perdagangan khamer."

SYARIKAT : Jurnal Rumpun Ekonomi Syariah Volume 2, Nomor 1, Juni 2019 
Bukhari No. 439; Abu Abdullah Muhammad bin Ismail Al-Bukhari, t.th: No. 439).

Hadis Bukhari No. 439 diatas didukung dengan 10 hadis dari beberapa riwayat, yaitu: 3 hadis dari riwayat bukhri, 2 hadis dari riwayat muslim, 4 hadis dari riawayat ahmad. Lihat mausu'ah hadis kutub alTis'ah berikut ini:

Tabel 2: Mausu'ah Hadis Kutub Al-Tis'ah

\begin{tabular}{|c|c|c|c|c|}
\hline No & No Hadis & Perawi & Judul dalam Kitab Hadis & Teks Naskah Arab Kitab Hadis \\
\hline 1 & 4177 & Bukhari & $\begin{array}{l}\text { [Bab] Surat al Baqarah ayat } \\
276\end{array}$ & يمحق الله الربا \\
\hline 2 & 4178 & Bukhari & $\begin{array}{l}{[\mathrm{Bab}] \text { Surat al Baqarah ayat }} \\
279\end{array}$ & فأذنوا بحرب من الله ورسوله \\
\hline 3 & 4179 & Bukhari & $\begin{array}{l}\text { [Bab] Surat al Baqarah ayat } \\
280\end{array}$ & تصدقوا خير لكم عسرة فنظرة إلى ميسرة وأن \\
\hline 4 & 2958 & Muslim & Haramnya bisnis khamer & تحريم بيع الخمر \\
\hline 5 & 2959 & Muslim & Haramnya bisnis khamer & تحريم بيع الخمر \\
\hline 6 & 20755 & Ahmad & $\begin{array}{l}\text { Hadits Usamah bin Zaid } \\
\text { kecintaan Rasulullah saw }\end{array}$ & عليه وسلم أسامة بن زيل حب رسول الله صلى الله \\
\hline 7 & 20779 & Ahmad & $\begin{array}{l}\text { Hadits Usamah bin Zaid } \\
\text { kecintaan Rasulullah saw }\end{array}$ & عليه وسلم أسامة بن زيد حب رسول الله صلى الله \\
\hline 8 & 20796 & Ahmad & $\begin{array}{l}\text { Hadits Usamah bin Zaid } \\
\text { kecintaan Rasulullah saw }\end{array}$ & عليه وسلم أسامة بن زيل حب رسول الله صلى الله \\
\hline 9 & 23551 & Ahmad & Hadits Sayyidah 'Aisyah Rah & حليث السيدة عائشة رضي الله عنها \\
\hline 10 & 24400 & Ahmad & Lanjutan Musnad yang lalu & باقي المسند السابق \\
\hline
\end{tabular}

Sedangkan hadis nomor 1943 dalam kitab shahih bukhari, maka akan muncul pada Kitab: Jual beli, Bab: Pemakan riba, saksi dan penulisnya, No. Hadist: 1943, hadisnya sebagai berikut:

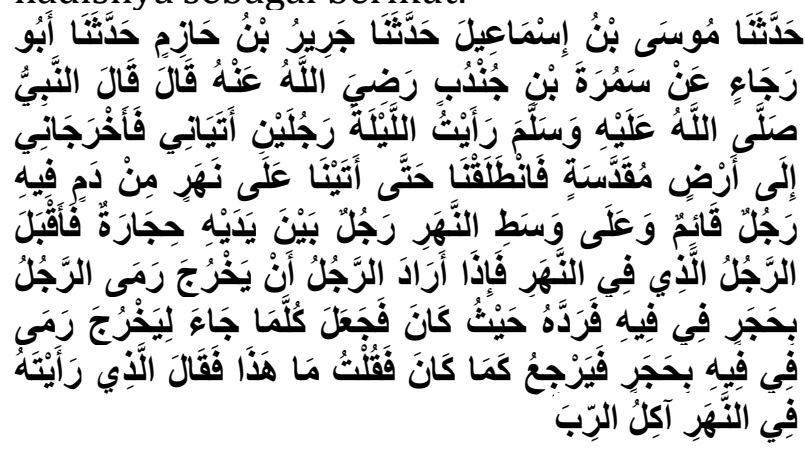

Artinya: Telah menceritakan kepada kami Musa bin Isma'il telah menceritakan kepada kami Jarir bin Hazim telah menceritakan kepada kami Abu Raja' dari Samrah bin Jundub radliallahu 'anhu berkata; Nabi shallallahu 'alaihi wasallam bersabda: "Pada suatu malam aku bermimpi dua orang menemuiku lalu keduanya membawa aku keluar menuju tanah suci. Kemudian kami berangkat hingga tiba di suatu sungai yang airnya dari darah. Disana ada seorang yang berdiri di tengah

SYARIKAT : Jurnal Rumpun Ekonomi Syariah Volume 2, Nomor 1, Juni 2019 
sungai dan satu orang lagi berada (di tepinya) memegang batu. Maka lakilaki yang berada di tengah sungai menghampirinya dan setiap kali dia hendak keluar dari sungai maka lakilaki yang memegang batu melemparnya dengan batu kearah mulutnya hingga dia kembali ke tempatnya semula di tengah sungai dan terjadilah seterusnya yang setiap dia hendak keluar dari sungai, akan dilempar dengan batu sehingga kembali ke tempatnya semula. Aku bertanya: "Apa maksudnya ini?" Maka orang yang aku lihat dalam mimpiku itu berkata: "Orang yang kamu lihat dalam sungai adalah pemakan riba'". (HR Bukhari No. 1943; Abu Abdullah Muhammad bin Ismail Al-Bukhari, t.th: No. 1943).

Hadis Bukhari No. 1943 diatas didukung dengan 6 hadis dari beberapa riwayat, yaitu: 1 hadis dari riwayat ahmad. Lihat mausu'ah hadis kutub al-Tis'ah berikut ini:

Tabel 3: Mausu'ah Hadis Kutub Al-Tis'ah

\begin{tabular}{|c|c|c|c|}
\hline No & No Hadis & Perawi & Judul dalam K \\
\hline 1 & 19306 & Ahmad & $\begin{array}{l}\text { Dan dari Hadits S } \\
\text { Jundub dari Nabi s }\end{array}$ \\
\hline \multicolumn{4}{|c|}{$\begin{array}{l}\text { Sedangkan hadis nomor } 1944 \text { dalam } \\
\text { shahih bukhari, maka akan muncul }\end{array}$} \\
\hline
\end{tabular}

Artinya: Telah menceritakan kepada kami Abu Al-Walid telah menceritakan kepada kami Syu'bah dari 'Aun bin Abu Juhaifah berkata, aku melihat bapakku membeli seorang budak sebagai tukang bekam lalu aku tanyakan kepadanya maka dia berkata; Nabi shallallahu 'alaihi wasallam telah melarang harga (uang hasil jual beli) anjing, darah dan melarang orang yang membuat tato dan yang minta ditato dan pemakan riba' dan yang meminjam riba serta melaknat pembuat patung". (HR Bukhari No. 1944; Abu
Teks Naskah Arab Kitab Hadis

ومن حديث سمرة بن جندب عن النبي صلى الله عليه وسلم

Abdullah Muhammad bin Ismail AlBukhari, t.th: No. 1944).

Hadis Bukhari No. 1944 diatas didukung dengan 15 hadis dari beberapa riwayat, yaitu: 5 hadis dari riwayat bukhari, 1 dari riwayat abu daud, 1 dari riwayat nasa'i, 1 dari riwayat ibnu majah dan 7 dari riwayat nasa'i dan 4 hadis dari riawayat ahmad. Lihat mausu'ah hadis kutub al-Tis'ah berikut ini: 
Tabel 4: Mausu'ah Hadis Kutub Al-Tis'ah

\begin{tabular}{|c|c|c|c|c|}
\hline No & No Hadis & Perawi & Judul dalam Kitab Hadis & Teks Naskah Arab Kitab Hadis \\
\hline 1 & 2084 & Bukhari & Harga anjing & ثمن الكلب \\
\hline 2 & 4927 & Bukhari & $\begin{array}{l}\text { Mahar untuk wanita pelacur } \\
\text { dan nikah yang rusak }\end{array}$ & مهر البغي والنكاح الفاسد \\
\hline 3 & 5319 & Bukhari & Dunia tenung menenung & 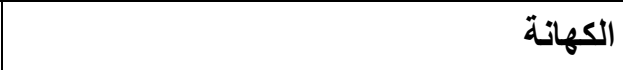 \\
\hline 4 & 5489 & Bukhari & Tato & الواشمة \\
\hline 5 & 5505 & Bukhari & Yang melaknat penggambar & من لعن المصور \\
\hline 6 & 3022 & $\begin{array}{l}\text { Abu } \\
\text { Daud }\end{array}$ & $\begin{array}{l}\text { Penjelasan tentang harga } \\
\text { anjing }\end{array}$ & في أثمان الكلاب \\
\hline 7 & 4596 & Nasa'i & Jual beli sperma unta & 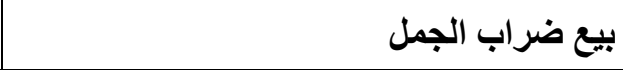 \\
\hline 8 & 2151 & $\begin{array}{l}\text { Ibnu } \\
\text { Majah }\end{array}$ & $\begin{array}{l}\text { Larangan mengambil harga } \\
\text { anjing, upah pelacur dan } \\
\text { dukun }\end{array}$ & الكاهن وعنب ثمن الكلب ومهر البغي وحلوان \\
\hline 9 & 2495 & Ahmad & $\begin{array}{l}\text { Awal Musnad Abdullah bin Al } \\
\text { 'Abbas }\end{array}$ & بداية مسند عبد الله بن العباس \\
\hline 10 & 3103 & Ahmad & $\begin{array}{l}\text { Awal Musnad Abdullah bin Al } \\
\text { 'Abbas }\end{array}$ & بداية مسند عبد الله بن العباس \\
\hline 11 & 13891 & Ahmad & $\begin{array}{l}\text { Musnad Jabir bin Abdullah } \\
\text { Radliyallahu ta'ala 'anhu }\end{array}$ & مسند جابر بن عبد الله رضي الله تعالى عنه \\
\hline 12 & 14125 & Ahmad & $\begin{array}{l}\text { Musnad Jabir bin Abdullah } \\
\text { Radliyallahu ta'ala 'anhu }\end{array}$ & مسند جابر بن عبد الله رضي الله تعالى عنه \\
\hline 13 & 14274 & Ahmad & $\begin{array}{l}\text { Musnad Jabir bin Abdullah } \\
\text { Radliyallahu ta'ala 'anhu }\end{array}$ & مسند جابر بن عبد الله رضي الله تعالى عذه \\
\hline 14 & 18007 & Ahmad & $\begin{array}{l}\text { Hadits Abu Juhaifah } \\
\text { Radliyallahu ta'ala 'anhu }\end{array}$ & حليث أبي جحيفة رضي الله تعالى عنه \\
\hline 15 & 18019 & Ahmad & $\begin{array}{l}\text { Hadits Abu Juhaifah } \\
\text { Radliyallahu ta'ala 'anhu }\end{array}$ & ج جيفة رضي الله تعالى عنه \\
\hline
\end{tabular}

Sedangkan hadis nomor 2032 dalam kitab shahih bukhari, maka akan muncul pada Kitab: Jual beli, Bab: Menjual dinar dengan dinar secara tempo, No. Hadist: 2032, hadisnya sebagai berikut:

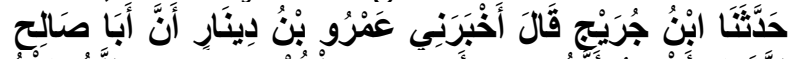

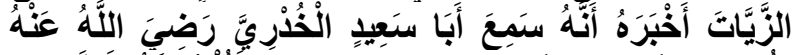

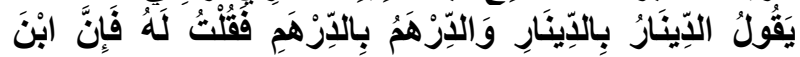

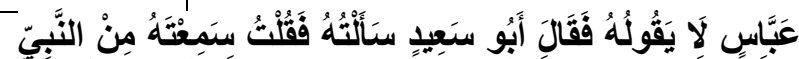

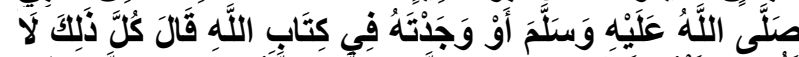

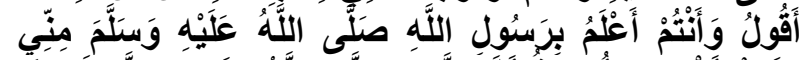

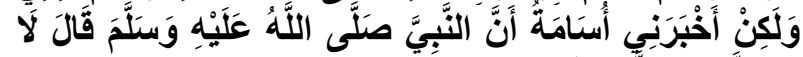

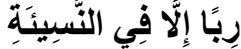
Artinya: Telah menceritakan kepada kami 'Ali bin 'Abdullah telah menceritakan kepada kami Adh Dhahhak bin

SYARIKAT : Jurnal Rumpun Ekonomi Syariah Volume 2, Nomor 1, Juni 2019 
Makhlad telah menceritakan kepada kami Ibnu Juraij berkata, telah mengabarkan kepada saya 'Amru bin Dinar bahwa Abu Shalih Az Zayyat mengabarkan kelpadanya bahwa dia mendengar Abu Sa'id Al Khudriy radliallahu 'anhu berkata: "Dinar dengan dinar dan dirham dengan dirham". Aku berkata kepadanya bahwa Ibnu 'Abbas radliallahu 'anhuma tidak mengatakan seperti itu. Maka Abu Sa'id berkata: "Aku pernah bertanya kepadanya dimana aku katakan apakah kamu mendengarnya dari Nabi shallallahu 'alaihi wasallam atau kamu mendapatkan keterangannya dari Kitab Allah?. Maka dia menjawab: "Semuanya itu aku tidak pernah mengatakannya. Dan kalian lebih mengetahui Rasulullah shallallahu 'alaihi wasallam daripada aku namun Usamah mengabarkan kepadaku bahwa Nabi shallallahu 'alaihi wasallam berkata: "Tidak ada riba, kecuali riba' nasi'ah" (ribadalam urusan pinjam meminjam dengan ada tambahan). (HR Bukhari No. 2032; Abu Abdullah Muhammad bin Ismail AlBukhari, t.th: No. 2032).

Hadis Bukhari No. 6894 diatas didukung dengan 4 hadis dari beberapa riwayat, yaitu: 1 hadis dari riwayat muslim, 1 dari riwayat nasa'I, 1 hadis dari riawayat ahmad dan 1 dari riwayat malik. Lihat mausu'ah hadis kutub al-Tis'ah berikut ini:

Tabel 5: Mausu'ah Hadis Kutub Al-Tis'ah

\begin{tabular}{|c|c|c|c|c|}
\hline No & No Hadi & \begin{tabular}{l|l} 
is & Perawi
\end{tabular} & Judul dalam Kitab Hadis & Teks Naskah Arab Kitab Hadis \\
\hline 1 & 2974 & Muslim & $\begin{array}{l}\text { Sharaf dan jual beli emas dan } \\
\text { perang dengan tunai }\end{array}$ & الصرف وبيع الذهب بالورق نقدا \\
\hline 2 & 4491 & Nasa'i & Membeli dinar dengan dinar & بيع الدينار بالدينار \\
\hline 3 & 8580 & Ahmad & $\begin{array}{l}\text { Musnad Abu Hurairah } \\
\text { Radliyallahu 'anhu }\end{array}$ & مسند أبي هريرة رضي الله عنه \\
\hline 4 & 1144 & Malik & $\begin{array}{l}\text { Menjual emas dengan perak } \\
\text { batangan atau perak yang } \\
\text { berujud uang }\end{array}$ & بيع الذهب بالفضة تبرا وعينا \\
\hline
\end{tabular}

Sedangkan hadis nomor 4180 dalam kitab shahih bukhari, maka akan muncul pada Kitab: Tafsir Al-Qur`an, Bab: [Bab] Surat al Baqarah ayat 280, No. Hadist: 4180, hadisnya sebagai berikut:

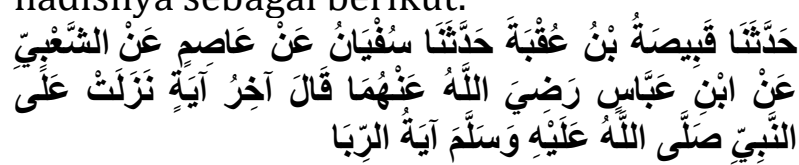

Artinya: Telah menceritakan kepada kami Qabishah bin Uqbah Telah menceritakan kepada kami Sufyan dari 'Ashim dari As Sya'bi dari Ibnu
Abbas radliallahu 'anhuma dia berkata; Ayat terakhir yang di turunkan kepada Nabi shallallahu 'alaihi wasallam adalah ayat tentang riba.' (HR Bukhari No. 4180; Abu Abdullah Muhammad bin Ismail Al-Bukhari, t.th: No. 4180).

Hadis Bukhari No. 4180 diatas didukung dengan 2 hadis dari beberapa riwayat, yaitu: 1 hadis dari riwayat ibnu majah dan 1 hadis dari riawayat ahmad. Lihat mausu'ah hadis kutub al-Tis'ah berikut ini:

SYARIKAT : Jurnal Rumpun Ekonomi Syariah Volume 2, Nomor 1, Juni 2019 
Tabel 6: Mausu'ah Hadis Kutub Al-Tis'ah

\begin{tabular}{|c|c|l|l|r|}
\hline No & No Hadis & Perawi & Judul dalam Kitab Hadis & Teks Naskah Arab Kitab Hadis \\
\hline 1 & 2267 & $\begin{array}{l}\text { Ibnu } \\
\text { Majah }\end{array}$ & Teguran keras dalam riba & \\
\hline 2 & 17894 & Ahmad & $\begin{array}{l}\text { Hadits Al Barra` bin 'Azib } \\
\text { Radliyallahu ta'ala 'anhu }\end{array}$ & التظيث البراء بن عازب رضي الله تعالى عنه الربا \\
\hline
\end{tabular}

\section{SIMPULAN}

Hasil penelitian dapat disimpulkan bahwa dalam kitab mausu'ah al-hadis alNabawiyah, dari persepktif shahih bukhari, maka hadis yang berkaitan dengan riba, penulis temukan ada 86 hadis dari riwayat bukhari. Dari 86 tersebut diambil sampel 5 hadis, yaitu hadis nomor 439 dalam kitab shahih bukhari, maka akan muncul pada Kitab: Shalat, Bab: Haramnnya memperdagangkan khamer di dalam masjid (sebelum turun ayat pengharaman meminumnya), No. Hadist : 439. Hadis Bukhari No. 439 diatas didukung dengan 10 hadis dari beberapa riwayat, yaitu: 3 hadis dari riwayat bukhri, 2 hadis dari riwayat muslim, 4 hadis dari riawayat ahmad. Selanjutnya hadis nomor 1943 dalam kitab shahih bukhari, maka akan muncul pada Kitab: Jual beli, Bab: Pemakan riba, saksi dan penulisnya, No. Hadist: 1943. Hadis Bukhari No. 1943 diatas didukung dengan 6 hadis dari beberapa riwayat, yaitu: 1 hadis dari riwayat ahmad. Kemudian hadis nomor 1944 dalam kitab shahih bukhari, maka akan muncul pada Kitab: Jual beli, Bab: Orang yang memberi makan riba, No. Hadist: 1944. Hadis Bukhari No. 1944 diatas didukung dengan 15 hadis dari beberapa riwayat, yaitu: 5 hadis dari riwayat bukhari, 1 dari riwayat abu daud, 1 dari riwayat nasa'i, 1 dari riwayat ibnu majah dan 7 dari riwayat nasa'i dan 4 hadis dari riawayat ahmad. Terahir hadis nomor 2032 dalam kitab shahih bukhari, maka akan muncul pada Kitab: Jual beli, Bab: Menjual dinar dengan dinar secara tempo, No. Hadist: 2032. Hadis Bukhari No. 6894 diatas didukung dengan 4 hadis dari beberapa riwayat, yaitu: 1 hadis dari riwayat muslim, 1 dari riwayat nasa'I, 1 hadis dari riawayat ahmad dan 1 dari riwayat malik.

\section{DAFTAR RUJUKAN}

A'jal, Muhammad, Al-khatib. 2015. Pokokpokok Ilmu Hadis. Jakarta: Gaya media pratama, 2015

Abdullah, Abu, Muhammad bin Ismail AlBukhari bin Ibrahim bin AlMughirah bin Bardizbah. t.th. Imam al-Bukhari, Sahih Bukhari. Bairut: Darul Ibnu Katsir al-Yammah.

Agama, Departemen, RI. Al-Qur'an dan Terjemahanya. Semarang: Toha Putra, 2015

Al-Jaziri, Abdurrahman. Kitab al-fiqh 'ala al-Mazahib al-Arba'ah. Beirut: dar alFikr. 1972

Al-Shalih, Subhi. Membahas IImu IImu Hadis. Jakarta: pustaka firdaus, 2007

Iskandar. Metode Penelitian Kualitatif : Aplikasi untuk Penelitian Pendidikan, Hukum, Ekonomi \& Manajemen, Sosial, Humaniora, Politik, Agama dan Filsafat. Jakarta: Gaung Persada, 2010

Majid, Abdul, Khon. Ulum al-Hadits. Jakarta: Amzah. 2010 
Moleong, Lexy J. Metodologi Penelitian Kualitatif. Bandung: Remaja Rosdakarya. 2001

Muslim. Tinjauan Syariat Terhadap JualBeli Kredit, lihat di wibesite online https://muslim.or.id/20961tinjauan-syariat-terhadap-jual-belikredit.html.diakses tanggal 20 september. 2018

Nawawi, Hadari. Metode Penelitian Bidang Sosial. Yogyakarta: Gajah Mada University Press. 2009

Rahman, Fatchur. Ikhtisar Mushtalahul Hadits. Bandung: PT Alma 'arif. 2014

Sura'I, Abu, Abdul Hadi. Bunga Bank Dalam Islam, alih bahasa M. Thalib. Surabaya: al-Ikhlas. 2013

Syamsul, Boy, Bakhri. Sistem Ekonomi Islam dalam Perbandingan. Jurnal Alhikmah Vol. 8, No. 1, April ISSN 1412-5382. 2011

Yuslem, Nawir. Kitab Induk Hadis. Jakarta: Hijir Pustaka Utama. 2016 